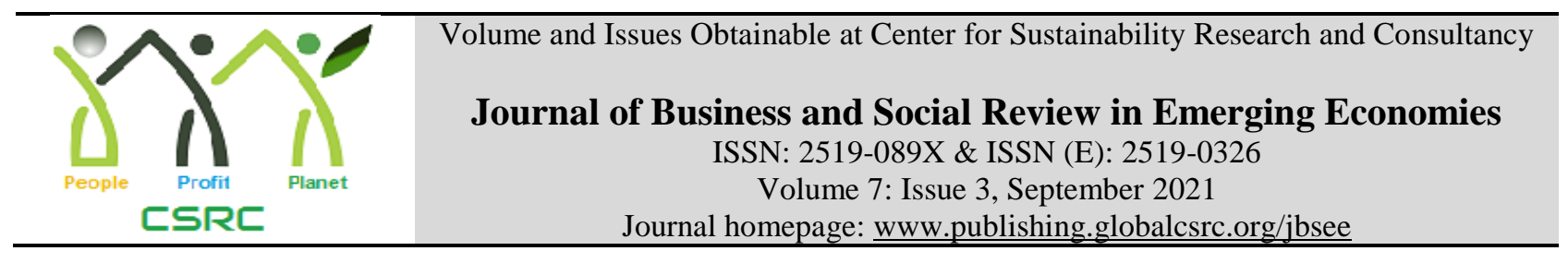

\title{
Infrastructural Investments and Economic Growth: Evidence from Pakistan
}

\author{
Muhammad Ayub, School of Economics, Bahauddin Zakariya University, Multan, Pakistan \\ Rabia Rasheed, Iqra University, Karachi, Pakistan \\ Rashid Ahmad, School of Economics, Bahauddin Zakariya University, Multan, Pakistan \\ *Furrukh Bashir, School of Economics, Bahauddin Zakariya University, Multan, Pakistan
}

*Corresponding author's email: furrukh@bzu.edu.pk

\begin{tabular}{l} 
ARTICLE DETAILS \\
History \\
Revised format: Aug 2021 \\
Available Online: Sep 2021 \\
\hline
\end{tabular}

\section{Keywords}

Investment in Railways,

Investment in Roads,

Projects,

Investment in Gas Projects,

Investment in Telecom,

Investment in Water.

JEL Classification Codes

E24, F43, H54, L91, L92,

L95, L96, \begin{abstract}
Purpose: The goal of this study is to make an attempt to find out the relationships between infrastructural investments and economic growth.

Design/Methodology/Approach: The study employs time series data over the years from 1972 to 2020 . To observe the long-run and short-run impact of infrastructural investments on economic growth, an ARDL modeling approach to co- integration is used that is most suitable technique over some other techniques of integration after inspecting the stationary level of data via ADF test.

Findings: The findings of the study indicate that Investments on Railways, Roads, Gas Projects, Telecommunication, Water Projects and Power Projects appear as efficient factors for enhancing economic growth of Pakistan in the long run.

Implications/Originality/Value: It is suggested that government should increase the public and private investment for development of Railways, Roads, Telecommunication and Water projects in Pakistan.
\end{abstract}

(C2021 The authors, under a Creative Commons AttributionNonCommercial4.0

Recommended citation: Ayub, M., Rasheed, R., Ahmad, R. and Bashir, F. (2021). Infrastructural Investments and Economic Growth: Evidence from Pakistan. Journal of Business and Social Review in Emerging Economies, 7(3), 591-598.

\section{Introduction}

Pakistan is included in those developing countries which needed a more improvement in infrastructure development for the enhancement in long run economic growth. The accumulation of capital is an important factor in increasing the level of infrastructure investment which has boosted the economic growth of the world's economies. Infrastructure development is such an important element of economic growth that no economy in the world can move forward without standard growth in infrastructure investment. Infrastructure investment has a strong impact on the short-term and long-term economic growth of any economy. The core and crucial role of the infrastructure development in the economic wellbeing of society and for economic growth has been well recognized in the study (Fedderke et al, 2006; Caldernon and Serven, 2004; Roller and Waverman, 2001; Albala-Bertrand and Mamatzakis, 2001; Aschauer, 1989). Infrastructure 
development can play a crucial role for long run-economic growth as well as for the wellbeing of the society and create an investment friendly environment. If the conditions of the infrastructure improved then the economy of Pakistan has the potential to grow fast. Improved conditions of infrastructure can attract the foreign investors as well as the domestic investors.

Pakistan can reduce the poverty, sustained its economic growth, can reduce unemployment and recover its economy by improving the conditions of essential public infrastructure. Infrastructure development is very essential and basic requirement for any economy to boost the economic growth. Infrastructure contains the structure like energy, telecommunications transmission, electric grid and rail links roads and so on. Further, the infrastructure development enhanced the economic growth indirectly and directly in multiple and different ways (Estache, 2006). Infrastructure development creates the better conditions for employment opportunities and gives the better social and physical infrastructure in the economy. Infrastructure development provides the improving conditions of competitiveness and decelerates the cost of trade and transactions which attract the investment in multiple sectors of the economy. It stimulates not only the economic wellbeing of the society but also provides the production facilities in the economy. On the other hand, the low and poor level of infrastructure investment produces the bottleneck in the track of sustainable economic growth and reduction in poverty. Therefore, the enhancement in infrastructure development works as a tool to provide the best resources in agriculture and manufacture sectors and improve the efficiency and activity of these sectors which are the back bone of the economy.

Many surveys have depicted that the main hurdles and impediments in the path of trade and business activities are due to the poor and low conditions of infrastructure in Pakistan. The policymakers of Pakistan have recognized that without improving the conditions of infrastructure, higher economic growth and stimulating activities of trade and business cannot be possible and attainable. The developments in infrastructure boost up the economic growth and provide the facility for enhancing the business and trade activities (Louw et al, 2013). The government sector has played a very important role for enhancing the infrastructure development economic growth. The next sections of the study are constructed as follows; in section 2 literature review of different studies is given while the data of included variables and methodology of the study is given in section 3. The empirical results about the variables of the study and discussion are presented in section 4. In the end, conclusion and policy implications of the study for infrastructure development and economic growth are recommended on the source of empirical results in section 5 .

\section{Literature Review}

Saidi, Shahbaz, and Akhtar (2018) investigated that infrastructure investment significantly enhanced economic growth in MENA countries. Bond (1999) examined that the improvement in basic infrastructure investment increased the conditions of the geographical desegregation, socio economic capital and environmental protection. Through the improvement in the infrastructure investment the socio-economic objectives and economic improvements could be attainable. Similarly, investment in water projects and provision of pure water to society could improve the health conditions of the people which would enhance the efficiency of people and contributed more in economic output. Hjort and Poulsen (2019) provided evidence for improving economic growth through enhancing capacity of infrastructure investment via skilled labor. The infrastructure investment decreased the cost of transportation and enhanced trade and economic growth (Coşar and Demir, 2016; Ehizuelen, 2017). Ivus and Boland (2015) depicted that digital infrastructure investment not only improved the employment level but also economic growth. Davidson and Mwakasonda (2004) depicted in their study that in the developing countries the accessibility of poor people to clean water, sanitation, electricity and telecommunications was very lower than other infrastructure facilities. The main hurdles in the provision of infrastructure 
facilities to poor people were the lack of reforms in the policies. Howells et al (2005) depicted in their study that the provision of electricity to the urban and rural areas enhanced the efficiency and health of the people in South Africa. Ndzendze and Monyae (2019) explored that investment on Belt and Road boosted economic growth in developing countries. Similarly, Mishra et al. (2020) examined that infrastructure investment increased the economic growth.

Szirmai and Verspagen (2015) examined that infrastructure investment is engine of economic growth. The causal relationship between infrastructure investment and economic growth was two dimensional although was not robust. The results of the study showed that infrastructure investment directly and indirectly improved the output and economic wellbeing. Infrastructure investment also enhanced the private and public investment which boosted up the economic, trade and business activities in the economy. The huge investment in electricity sector provided more fruitful results as the improvement in economic growth. Baum-Snow et al (2018) examined that infrastructure investment enhanced economic growth via improving employment level and lower transportation cost. Similarly, Zahra et al (2008) study determined the impact of telecommunications infrastructure development on economic growth followed the theory of Solow (1956) and used the panel data of twenty four countries and eighteen years. Two models have been developed, first random effect and second fixed effect to check out the macro level performance of including variables importance as factors of economic growth and causal relationship between telecommunications infrastructure development and economic growth. The results of the study found that the telecommunications infrastructure development has the robust impact on economic growth of developing countries and the investment in telecommunications infrastructure development has the capacity of increasing return to scale. Similarly, Achour and Belloumi (2016) found the unidirectional relationship between infrastructure investment and economic growth in Tunisia. Hiremath et al (2009) examined that the infrastructure investment at the small scale in the energy sector provided the employment opportunities to the vulnerable people of the society. This increased the agriculture and industrial productivity and provided the best facility to convey the agriculture products to the markets. Owusu et al (2020) investigated that infrastructure investment is an important part of economic growth in African economies.

Sahoo and Dash (2009) examined in their study following the theoretical framework of Romer (1987) and Solow (1956) using the data from 1970 to 2006 that the impact of infrastructure development was higher than public and private investment on output of the economy. Although the causal relationship between economic growth and infrastructure development was onedimensional and infrastructure development increased the economic growth but economic growth was not have the strong impact on the infrastructure development. The study emphasized that the government should give more attention to infrastructure development like other sectors of the economy which will increase the social and physical capital and this will automatically boost up the economic growth. Cook (2011) study revealed that the investment in the provision of electricity and telecommunications facilities from private sector was misplaced. The provision of electricity and telecommunications must be included in the huge investment projects which would improve the economic conditions of poor people and will increase the efficiency and experience of poor people in rural areas. Many studies have seen the impact of infrastructure investment on economic growth (Mayer and Trevien, 2017; Boccanfso et al, 2009). The infrastructure investment in different sectors has the strong impact on long-run economic. The result of studies showed that the enhancement in infrastructure development attracted the foreign and domestic investment in the country and relaxes the sectors of trade and businesses which boosted the economic growth. Finally, study found that the telecommunications infrastructure development boosted the economic growth of developing countries. The infrastructure development not only enhanced the level of employment but also stimulated the trade and business activities in the European region. Infrastructure developments also improved the social capital in the region and provided more facility to access to market to the people of the region. 
Infrastructure development increased the competiveness among firms and awareness among the society (Louw, 2013).

\section{Data and Methodologies}

Present study is based on secondary sources of data that covers the time period from 1972 to 2020. The data is collected from Handbook of Statistics, Pakistan economic survey (various issues), World Bank Indicators (WDI) and Board of Investment (BOI). The variables for which data has been collected are GDP, employment level and investments in the sectors of water, telecommunications, gas, power, railways and roads. The study considers the Cobb-Douglas form of production function to investigate the relationship between investment on infrastructure and economic growth.

$$
\begin{aligned}
& Y=\alpha_{0} K^{\alpha} L^{(1-\alpha)} e^{\varphi} \ldots \ldots \ldots(a) \\
& K=f(I R D, I R L, I G, I T, I W, I P) \ldots \ldots . .(b)
\end{aligned}
$$

Where ILR (Investment in Railway Lines Projects), IRD (Investment in Roads Projects), IG (Investment in Gas Projects), IT (Investment in Telecommunications Sector), IW (Investment in Water Projects) and IP (Investment in Power Projects) used as proxy for capital, GDP (Gross Domestic Product) as proxy for economic growth and EMP (employed labor force) as proxy of labor. Natural log is taken on both sides of the above equation "a" to make the linear equatio.

$$
L G D P=\theta_{0}+\theta_{1} L I R D+\theta_{2} L I R L+\theta_{3} L I P+\theta_{4} L I G+\theta_{5} L I W+\theta_{6} L I T+\theta_{7} L E M P+\varphi_{t .}
$$

GDP (gross domestic product) in the model is taken as a proxy of economic growth and used as a dependent variable while employment, investment in sectors of water, telecommunications, gas, power, railways and roads as independent variables. The investment in telecommunications, water and power enhanced the economic growth and appreciated the trade and business activities (Boccanfso et al, 2009). Similarly, the enhancement in the development of roads and railways links boosted up the economic activities in the economy and ultimately the output in long run (Adam and Bevan, 2004). The analysis is based on the following steps as given below;

$1^{\text {st }}-\quad$ Stationarity test

The stationarity of the data is examined using Augmented Dickey Fuller (ADF) test. All variables included in the model depict the stationary at first difference or level. The variables in the model are stationary at I (1) and at I (0). Thus, to apply other methodology such as OLS (ordinary least square) will mislead the findings.

$2^{\text {nd }}-\quad$ Choosing Appropriate Technique

The ARDL (autoregressive distributed lag model) technique is used to find out the precise findings.

\section{Advantages of ARDL}

In this study, ARDL approach is used which estimate the variables' parameters in short-run and long-run simultaneously. The estimated parameters of variables found after applying ARDL are unbiased and efficient. The ARDL technique is efficient for large and small sample size. The methodologies of Engel-Granger and Johansen are not efficient for small sample size (Narayan 2004). It is not necessary that all including variables should at same order of first difference and at level in ARDL. The methodology of ARDL can be used in any order of integration (i.e. first difference or level). This technique is not applicable for those models which consist such variables which have stationary level higher than the first difference. The ARDL is comprised on two stages. First, to check the significance of variables' lagged values F-test is applied which determine the long-run relationship among variables. Second, signs of variables, coefficients and 
their magnitudes are analyzed in short-run and long-run among variables. Bound test has three assumptions. First, confirm the integration order of variable. Second, order of integration of variables is not restricted to have same order. Third, VAR (vector auto-regression) of order $p$ is used for small sample size which can be represented as Pesaran et al (2001).

\section{Results and Discussion}

The statistics of the ADF test for the variables are presented in Table 2. According to the results of the ADF test, Gross Domestic Product (LGDP), Investment in Railway Lines Projects (LIRL), Investment in Gas Projects (LIG), Investment in Telecommunications Sector (LIT), Employed Labor Force (LEMP) are stationary at $1^{\text {st }}$ difference while Investment in Roads Projects (LIRD), Investment in Power Projects (LIP) and Investment in Water Projects (LIP) are stationary at level. The findings of the study supported the use of the ARDL approach.

Table 2: The Findings of ADF Test

\begin{tabular}{ccccccc}
\hline Variables & Parameters & ADF Calculated & At 5\% & Lag Values & $\begin{array}{c}\text { Trend/ } \\
\text { Intercept }\end{array}$ & Conclusions \\
\hline LGDP & -0.37 & -3.58 & -2.94 & 1 & Trend & $\mathrm{I}(1)$ \\
LIRD & -1.40 & -5.86 & -3.53 & 1 & Trend/Intercept & $\mathrm{I}(0)$ \\
LIRL & -0.08 & -4.30 & -1.94 & 1 & None & $\mathrm{I}(1)$ \\
LIP & -0.62 & -2.25 & -1.94 & 1 & None & $\mathrm{I}(0)$ \\
LIG & -1.007 & -4.27 & -2.94 & 1 & Intercept & $\mathrm{I}(1)$ \\
LIW & -0.25 & -3.07 & -2.93 & 1 & Intercept & $\mathrm{I}(0)$ \\
LIT & -0.99 & -4.16 & -2.93 & 1 & Intercept & $\mathrm{I}(1)$ \\
EMP & -0.80 & -4.89 & -3.52 & 1 & Intercept & $\mathrm{I}(1)$ \\
\hline
\end{tabular}

Note: The Results of the Table 2 are based on author's self-calculations

In Table 3, the first column shows the including variables while the second column displays the F-statistics based on the Wald test and the third column displays the lower and upper bound values.

Table 3: Bound Testing Results for Co-integration

\begin{tabular}{ccccc}
\hline & & \multicolumn{2}{c}{ Critical Bound } & Conclusion \\
\cline { 3 - 5 } Model & $\begin{array}{c}\text { F-statistics } \\
\text { Calculated }\end{array}$ & $\begin{array}{c}\text { Lower- } \\
\text { Bound } \\
\text { Value }\end{array}$ & $\begin{array}{c}\text { Upper Bound } \\
\text { Value }\end{array}$ & \\
\hline LGDP/LIRD,LIRL,LIP,LIT, & & 3.35 & 4.34 & Co-integration \\
LIW,LIG,LEMP & $(0.0003)$ & $(99 \%)$ & $(99 \%)$ & exists \\
\hline
\end{tabular}

The results in the long run are presented in table 4 which shows that investments in roads projects, Railway Lines Projects, Power Projects, Gas Projects, Water Projects, and Telecommunication sectors are found to be a cause of higher Economic Growth of Pakistan. Similarly, employment is also increasing economic growth in long-run. These results are in the line with the results of Sahoo and Dash (2009). The investment in water projects increases the long run economic growth; however, the relationship is insignificant which are also matched with the earlier study i.e. Fedderke et al (2006). The investment in the sectors of telecommunications, power and gas are also enhancing the long run economic growth. These findings corroborate the findings of Bond (1999) and Cook (2011). The investment in railways also increased the longrun economic growth (Hiremath et al (2009)).

Table 5 shows the coefficients of variables in the short run. The result shows that investment in road projects is the source of increasing economic growth in short-run while investment in railways link and water projects decline the short-run economic growth. The investment in roads, in water projects and railways increase short-run economic growth. In the short run, these results are supported with Davidson and Mwakasonda's research (2004). Likewise, the result shows that 
investment in power projects increase the short-run economic growth which matches with the results of Howells et al (2005). Further, the investment in gas and telecommunications sectors enhance the economic growth in short run with significant effects and these results match with study of Hiremath et al (2009).

Table 4: Long- Run Results of Economic Growth

\begin{tabular}{lccc}
\hline \multicolumn{1}{c}{ Explanatory Variables } & Coefficients & $\begin{array}{c}\text { Standard } \\
\text { Errors }\end{array}$ & $\begin{array}{c}\text { T-Ratio } \\
\text { (Probability) }\end{array}$ \\
\hline Investment in Roads Projects & 11.86 & 5.47 & $2.16[0.042]$ \\
Investment in Railway Lines Projects & 0.45 & 0.109 & $4.12[0.033]$ \\
Investment in Power Projects & 2.44 & 0.38 & $6.43[0.002]$ \\
Investment in Gas Projects & 4.78 & 1.52 & $3.13[0.005]$ \\
Investment in Water Projects & 0.297 & 0.333 & $0.89[0.489]$ \\
Investment in Telecommunications Sector & 12.29 & 2.12 & $5.78[0.019]$ \\
Employed Labor Force & 3.0 & 0.47 & $6.38(0.000)$ \\
Constant & 8.078 & 1.892 & $4.26[0.000]$ \\
Trend & 0.095 & 0.085 & $1.11[0.277]$ \\
\hline
\end{tabular}

Note: Results are based on Author's own calculations by using the Microfit

The error correction term of the $E C M_{t-1}$ for the equation has a value of (-0.596), indicating that in one year the short-run disequilibrium of the variables will approach to long run equilibrium by about $60 \%$. It is negative and statistically significant indicates that the variables in the model are co-integrated.

Table 5: Short Run Effects of Infrastructure investment on Economic Growth

\begin{tabular}{lccc}
\hline $\begin{array}{c}\text { Explanatory } \\
\text { Variables }\end{array}$ & Coefficients & Standard Error & T-Ratio (Probability) \\
\hline$\Delta$ LIRD & 0.40597 & 0.078013 & $5.2039[0.000]$ \\
$\Delta$ LIRL & -0.81764 & 0.27314 & $-2.9935[0.006]$ \\
$\Delta$ LIP & 1.16217 & 0.87698 & $1.8492[0.076]$ \\
$\Delta$ LIG & 0.13161 & 0.048468 & $2.7153[0.012]$ \\
$\Delta$ LIW & -0.55191 & 0.15896 & $-3.4720[0.002]$ \\
$\Delta$ LIT & 2.23509 & 0.92643 & $2.5376[0.017]$ \\
$\Delta$ LEMP & -3.1067 & 1.6227 & $1.9145(0.344)$ \\
$\Delta$ C & 8.0780 & 1.8928 & $4.2678[0.000]$ \\
$\Delta$ T & 0.095545 & 0.08564 & $1.1156[0.275]$ \\
ECM(-1) & -0.596 & 0.119 & $-5.002[0.0000]$ \\
R-Squared & 0.94362 & R-Bar-Squared & 0.89799 \\
DW-Statistic & 2.1464 & F-stat. F( 12, 26) & $29.2914[.000]$ \\
\hline
\end{tabular}

Note: Results are based on Author's own calculations by using the Microfit

\section{Conclusion and Policy Implication}

Economic growth of developing and developed countries relies on the level of investment, especially on infrastructure investment large extent. It is desirable to find out relationship between economic growth and infrastructure investment of Pakistan because the low level of infrastructural investment has become a central issue now-a-days in Pakistan. The study is aimed at investigating the relationship between Investments on Infrastructure and Economic growth of Pakistan during 1972 to 2020 . For estimation of results, ARDL method is utilized for having long run and short run relationship among the variables. The results of the study conclude that Investment in Road Projects, Railway Lines Projects, Power Projects, Gas Projects, Water Projects, Telecommunication Sector and Employed Labor Force are increasing Economic Growth of Pakistan in the long run.

The study's long-run findings revealed that investing in road projects boosts economic growth, implying that the government needs to increase public and private investment in road projects in the country. The government should also improve the level of employment which will increase 
the income of individuals and aggregate consumption of the economy. Improvements in the road infrastructure will provide the conducive environment for the trade and business activities. It will also connect the far away areas to the markets. The investment in railways links also increases the economic growth and shows that government should also encourage the private and public investment in railways links through which public can avail better opportunities for travelling and for the mobility of resources. The investment in water projects enhanced the economic growth which suggests that government should invest in water projects, so that clean water is provided to each individual in the economy. Clean and better availability of water to the society will increase the efficiency and health of the people which can play better role in the economy.

\section{References}

Achour, H., and Belloumi, M. (2016). Investigating the causal relationship between transportinfrastructure, transport energy consumption and economic growth in Tunisia. Renewable and Sustainable Energy Reviews, 56, 988-998.

Albala-Bertrand, J. M., \& Mamatzakis, E. C. (2001). Is public infrastructure productive? Evidence from Chile. Applied Economics Letters, 8(3), 195-198.

Aschauer, D. A. (1989). Public investment and productivity growth in the Group of Seven. Economic Perspectives, 13(5), 17-25.

Banerjee, A., Dolado, J., and Mestre, R. (1998). Error- correction mechanism tests for cointegration in a single- equation framework. Journal of Time Series Analysis, 19(3), 267-283.

Baum-Snow, N., Freedman, M., and Pavan, R. (2018). Why has urban inequality increased? American Economic Journal: Applied Economics, 10(4), 1-42.

Boccanfso. D, Estache. A, and Savard. L. (2009). A macro-micro analysis of the effects of electricity reform in Senegal on poverty and distribution. J Dev Stud, 45(2009). 351-68.

Bond, P. (1999). Basic infrastructure for socio-economic development, environmental protection and geographical desegregation: South Africa's Unmet Challenge. Geo Forum, 30(1), 4359.

Calderon, C. A., and Servén, L. (2004). The effects of infrastructure development on growth and income distribution. Available at SSRN 625277.

Cook, P. (2011). Infrastructure, rural electrification and development. Energy for Sustainable Development, 15 (2011), 304-313.

Coşar, A. K., and Demir, B. (2016). Domestic road infrastructure and international trade: Evidence from Turkey. Journal of Development Economics, 118, 232-244.

Davidson, O., \& Mwakasonda, S. A. (2004). Electricity access for the poor: a study of South Africa and Zimbabwe. Energy for Sustainable Development, 8(4), 26-40.

Ehizuelen, M. M. O. (2017). More African countries on the route: the positive and negative impacts of the Belt and Road Initiative. Transnational Corporations Review, 9(4), 341359.

Estache, A. (2006, February). Africa's infrastructure: Challenges and opportunities. In high level seminar: Realizing the Potential for Profitable Investment in Africa, Tunis, Tunisia.

Fedderke, J. W., Perkins, P., and Luiz, J. M. (2006). Infrastructural investment in long-run economic growth: South Africa 1875-2001. World Development, 34(6), 1037-1059.

Hiremath, R. B., Kumar, B., Balachandra, P., Ravindranath, N. H., and Raghunandan, B. N. (2009). Decentralised renewable energy: Scope, relevance and applications in the Indian context. Energy for Sustainable Development, 13(1), 4-10.

Hjort, J., and Poulsen, J. (2019). The arrival of fast Internet and employment in Africa. The American Economic Review, 109(3), 1032-1079.

Howells. M, Alfstad. T, Victor. D, Goldstein. G, and Remme. U. (2005). A model of household energy services in a low-income rural African village. Energy Policy, 33(2005).1833-51.

Ivus, O., and Boland, M. (2015). The employment and wage impact of broadband deployment in 
Canada. Canadian Journal of Economics, 48(5), 1803-1830.

Louw, E., Leijten, M., and Meijers, E. (2013). Changes subsequent to infrastructure investments: Forecasts, expectations and ex-post situation. Transport Policy, 29, 107-117.

Mayer, T., and Trevien, C. (2017). The impact of urban public transportation evidence from the Paris region. Journal of Urban Economics, 102, 1-21.

Mishra, S., Tewari, I., and Toosi, S. (2020). Economic complexity and the globalization of services. Structural Change and Economic Dynamics, 53, 267-280.

Ndzendze, B., and Monyae, D. (2019). China's belt and road initiative: linkages with the African Union's Agenda 2063 in historical perspective. Transnational Corporations Review, 11(1), 38-49.

Owusu, S., Szirmai, A., and Foster-McGregor, N. (2020). The rise of the service sector in the global economy. UNU-MERIT Working Paper Series \#2020-056.

Pesaran, M. H., Shin, Y., and Smith, R. J. (2001). Bounds testing approaches to the analysis of level relationships. Journal of Applied Econometrics, 16(3), 289-326.

Roller, L. H., and Waverman, L. (2001). Telecommunications infrastructure and economic development: A simultaneous approach. American Economic Review, 91(4), 909-923.

Romer, P. M. (1987). Growth based on increasing returns due to specialization. The American Economic Review, 77(2), 56-62.

Sahoo, P., and Dash, R. K. (2009). Infrastructure development and economic growth in India. Journal of the Asia Pacific Economy, 14(4), 351-365.

Saidi, S., Shahbaz, M., and Akhtar, P. (2018). The long-run relationships between transport energy consumption, transport infrastructure, and economic growth in MENA countries. Transportation Research Part A: Policy and Practice, 111, 78-95.

Szirmai, A., and Verspagen, B. (2015). Manufacturing and economic growth in developing countries, 1950-2005. Structural Change and Economic Dynamics, 34, 46-59.

Zahra. K, Azim. P, and Mahmood.A. (2008). Telecommunication Infrastructure Development and Economic Growth: A Panel Data Approach. The Pakistan Development Review, 47, 711-726. 